\title{
IMPACT OF QUR'AN RECITATION THERAPY ON PHYSIOLOGIC RESPONSES IN NEONATES ADMITTED IN NICU: A SYSTEMATIC REVIEW
}

\author{
Desriati Devi $^{1)}$, Yeni Rustina ${ }^{2)}$ \\ ${ }^{1,2}$ Pediatric Nursing Department of Faculty of Nursing of Universitas Indonesia \\ Corresponding Email: Desriati Devi (desriatidevi@gmail.com)
}

\begin{abstract}
Neonates who are admitted in NICU are exposed to tumultuous care environment originating from medical devices and procedures which may affect their physiological responses.This study aimed to identify the impact of Quran recitation therapy on physiological responses in neonates who were admitted in NICU. A systematic review was conducted by searching literatures of three databases including Science Direct, Scopus (2010-2018), and Google Scholar (2015-2018). The key words included "infants", "holy Qur'an recitation", and "Qur'an recitation" with inclusion criteria of literatures published in English language, Quasi-experimental study design, randomized controlled trials, neonates admitted in NICU as study sample, and impact of Quran recitation on physiological responses (oxygen saturation, respiratory rate, and pulse). The searching process resulted in 5 articles which met the inclusion criteria. The intervention of Quran recitation in those studies was performed once per day with duration of 10-25 minutes. The recited chapters included Al-Isra, Yusuf, Ar-Rahman, and Yasin. The intervention was provided through headphone with sound volume ranging from 45 to $65 \mathrm{~dB}$. Four out of five studies reported significant difference. Qur'an recitation therapy had a significant effect on physiological responses in neonates admitted in NICU, including lower pulse and respiratory rate as well as higher oxygen saturation. The therapy may be provided as complementary and supportive intervention in order to improve stability of physiological responses in neonates admitted in NICU.
\end{abstract}

Key words: Qur'an therapy; Physiological Responses; Neonates; NICU

\section{INTRODUCTION}

Newborn, especially premature or low birth weight neonate requires special or even intensive care due to various health issues affecting them. Neonatal Intensive Care Unit is an environment with various stressors including light and noises that may induce stress and provide both positive and negative impacts (Hunt, 2011; Rabold, 2013). One of common issues affecting neonates admitted in NICU is alteration in physiological responses such as altered respiratory and pulse rate (Caparros-Gonzales et al, 2017). Noises produced by medical devices may lead to apnea, affect oxygen consumption rate, and pulse instability (Brown, 2009; Wachman \& Lahav, 2010).

Pain may also affect physiological responses (Marofi et al, 2018). Newborns in care environment are exposed to invasive and non-invasive medical procedures on daily basis which result in stress and impair their physiological responses and behaviors (Boxwell, 2010). Newborns admitted in NICU are regularly exposed to 10-16 invasive procedures each day (Cong, Ludington-hoe, Mccain, \& Fu, 2009). (Cruz, Fernandes, \& Oliveira, 2016) claimed that hospitalized infants underwent 7-17 invasive procedures on average every day and the most common procedures included blood test and suction.

Stressors in care environment generate negative effects on neonates who require supportive intervention; audio stimulation is among the feasible options of intervention. Music stimulation is able to provide relaxing effect which lead to stability of physiological functions including respiratory rate, pulse, and oxygen saturation (Caparros-Gonzales et al, 2017; Loewy, Stewart, Dassler, Telsey, \& 
Homel, 2013), as well as relieve stress responses (Caparros-Gonzales et al, 2017).

Beside music therapy, audio stimulation may also be applied through murottal therapy or recitation of Quran verses. Quran recitation is a sound with specific frequency and rhythm that results in harmonious tone and provides positive results on brain cells (Nasiri, Shahdadi, \& Bandani, 2017). Qur'an recitation influences release of hormones and chemicals affecting anxiety thus provides relaxing effect (Sheka, Hassan, \& Othman, 2013). Qur'an recitation therapy may also be implemented as non-pharmacological intervention to improve physiological functions in newborns (Abbas et al., 2016). AlQur'an improves spiritual relaxation and balance of neural impulses (Zulkurnaini, Shilawani, Kadir, Murat, \& Isa, 2012).

\section{OBJECTIVE}

The systematic review aimed to identify impact of Quran recitation therapy on physiological responses in neonates admitted in NICU.

\section{METHOD}

The study design was systematic review by Preferred Reporting Items for Systematic Reviews and Meta-Analyses approach (Kleijnen et al., 2009). The searching process was initiated on October $22^{\text {nd }}$ and ended on November, $2^{\text {nd }} 2018$. The process involved 3 electronic databases including ScienceDirect, Scopus (2010-2018) and Google Shoolar (2015-2018) with following keywords: infant, holy Qur'an recitation, and Qur'an recitation. The review also involved articles acquired through hand searching.

The searching strategy started with initial screening based on title and abstract and followed by screening based on inclusion criteria. The inclusion criteria were articles published in English language, Quasiexperimental study design, randomized controlled trials, neonates admitted in NICU as study sample, and impact of Quran recitation on physiological responses (oxygen saturation, respiratory rate, and pulse). Studies with systematic review, correlation, and case study design, as well as thesis and published in language other than English language were excluded from this review.

\section{RESULT}

There were 710 articles acquired from searching in three databases. 688 articles were excluded following title and abstract screening, and there were only 3 articles left following the screening based on inclusion criteria with 2 additional articles which acquired through hand searching. Therefore, there were only 5 articles which met the inclusion criteria of this systematic review. The searching result is depicted in Figure 1 and description of 5 studies addressing Quran recitation therapy on physiological responses in neonates admitted in NICU is outlined in Table 1.

The intervention of Quran recitation in those 5 studies was conducted once per day with duration of 10-25 minutes. The recited chapters included Al-Isra, Yusuf, Ar-Rahman, and Yasin. The intervention was provided through headphone with volume ranging from 45 to $65 \mathrm{~dB}$. Three studies (Eskandari et al., 2014, Eskandari et al, 2012; Qolizadeh, Myaneh, \& Rashvand, 2018) used MP3 and headphone which placed on neonate's ears. A study conducted by (Majidipour et al., 2018) provided intervention with small speaker, headphone, and MP3 which placed next to side of neonate's head, and a study by (Marofi et al., 2018) only used MP3 which placed in patient's bed.

Marofi et al (2018) identified the effect of Qur'an therapy following blood collection and Majidipour et al (2018) evaluated the effect throughout phlebotomy procedure while the other 3 studies evaluated its effect after providing drinks, diaper changing, or routine care. The sample was selected by randomization on three studies only (Qolizadeh et al, 2018; Majidipour et al 2018; Marofi et al, 2018) which outlined sample randomization into intervention and control groups.

Qolizadeh et al (2018) evaluated physiological responses following Qur'an recitation intervention in 3 sessions: 10 minutes before the intervention, in the $10^{\text {th }}$ and $20^{\text {th }}$ minute of it, and 10 minutes after it. 
Eskandari et al (2014) evaluated its effect 10 minutes prior to the intervention, in the $5^{\text {th }}$, $10^{\text {th }}, 15^{\text {th }}$, and $20^{\text {th }}$ minute of intervention, and in the $5^{\text {th }}$ and $10^{\text {th }}$ minute following the intervention. Marofi et al (2018) conducted evaluation 3 minutes prior to the intervention, 3 minutes during the intervention, and 3 minutes after the intervention. Eskandari et al (2012) performed evaluation before the intervention, in the $10^{\text {th }}$ and $20^{\text {th }}$ minute of it, and in the $30^{\text {th }}$ or $10^{\text {th }}$ minute after it. Majidipour et al (2018) evaluated the effect 6 times: 5 minutes before the procedure, 5 minutes during phlebotomy procedure, and in the $5^{\text {th }}, 10^{\text {th }}, 15^{\text {th }}$, and $20^{\text {th }}$ minute following the procedure.
Based on study result, 4 studies (Qolizadeh et al, 2018; Marofi et al, 2018; Eskandari et al, 2012; Majidipour et al, 2018) reported significant difference between intervention and control group, while the study conducted by (Eskandari et al, 2014) revealed no significant difference. Physiological responses which were evaluated in those 5 studies included pulse, respiratory rate, and oxygen saturation. Qolizadeh et al (2018) also added other physiological responses including blood pressure and temperature; however, their study reported no significant difference in body temperature.

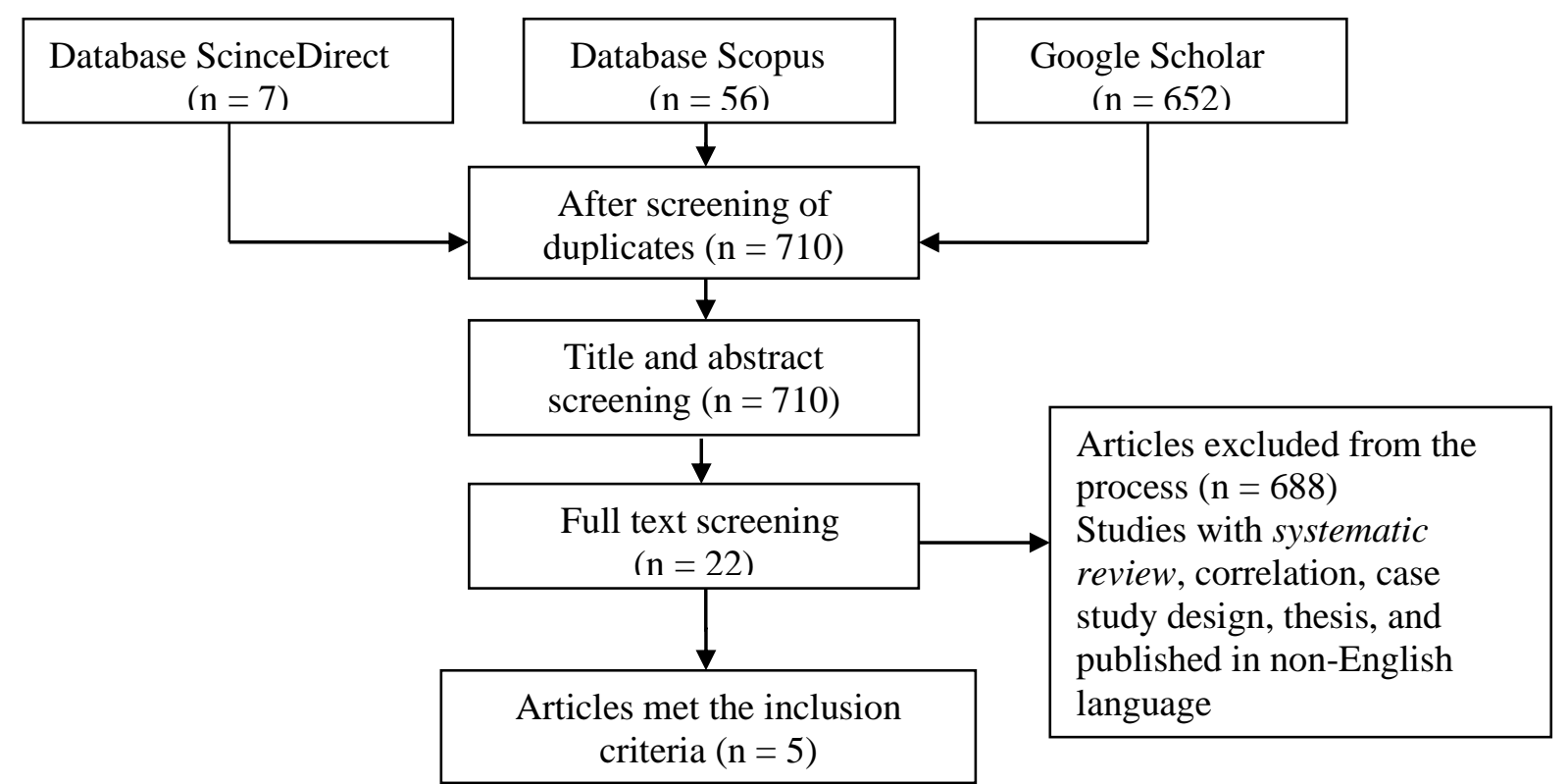

Figure 1 PRISMA Diagram of Systematic Review Searching 


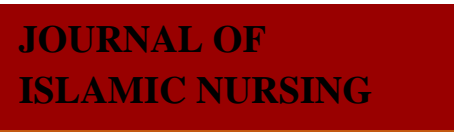

Table 1 Description of Journals from Searching Literatures Addressing Qur'an Therapy on Neonates in NICU

\begin{tabular}{|c|c|c|c|c|c|c|c|}
\hline No & $\begin{array}{c}\text { Author's Name } \\
\text { (Year) }\end{array}$ & Objective & Study Method & Sample & $\begin{array}{c}\text { Frequency, } \\
\text { Length \& } \\
\text { Duration of } \\
\text { Intervention }\end{array}$ & $\begin{array}{c}\text { Sound } \\
\text { Intensity }\end{array}$ & Result \\
\hline 1 & $\begin{array}{l}\text { Qolizadeh et al } \\
\qquad(2018)\end{array}$ & $\begin{array}{l}\text { To evaluate the } \\
\text { impact of } \\
\text { Qur'an } \\
\text { recitation on } \\
\text { physiological } \\
\text { responses in } \\
\text { newborns } \\
\text { admitted in } \\
\text { NICU }\end{array}$ & $\begin{array}{l}\text { Design: clinical } \\
\text { trial with } \\
\text { randomization } \\
\text { and assigning } \\
\text { participants into } \\
\text { intervention and } \\
\text { control group }\end{array}$ & $\begin{array}{l}64 \\
\text { premature } \\
\text { infants in } \\
\text { NICU }\end{array}$ & $\begin{array}{l}\text { Frequency: once } \\
\text { in the afternoon. } \\
\text { Duration of } \\
\text { study: } 1 \text { day } \\
\text { Duration of } \\
\text { intervention: } \\
\text { undescribed. }\end{array}$ & $45 \mathrm{~dB}$ & $\begin{array}{l}\text { Pulse rate was significantly lower } \\
\text { during intervention }(\mathrm{p}<0.001) \text { and } \\
10 \text { minutes following intervention } \\
(\mathrm{p}=0.028) \\
\text { Respiratory rate was significantly } \\
\text { lower during intervention } \\
(\mathrm{p}<0,001) \\
\text { Oxygen saturation was } \\
\text { significantly higher throughout } \\
\text { intervention ( } \mathrm{p}<0,001) \text { and } 10 \\
\text { minutes after it } \\
\text { Atrial pressure was significantly } \\
\text { reduced } \\
\text { There was no significant difference } \\
\text { in body temperature between both } \\
\text { groups }\end{array}$ \\
\hline 2 & $\begin{array}{c}\text { Eskandari et al } \\
\text { (2014) }\end{array}$ & $\begin{array}{l}\text { To identify the } \\
\text { effect of Qur'an } \\
\text { therapy, lullaby, } \\
\text { and silence on } \\
\text { physiological } \\
\text { and behavioral } \\
\text { responses in } \\
\text { premature } \\
\text { infants }\end{array}$ & $\begin{array}{l}\text { Design: } \\
\text { Double-blind } \\
\text { randomized } \\
\text { controlled trial } \\
\text { by assigning } \\
\text { participants into } \\
4 \text { groups }\end{array}$ & $\begin{array}{l}120 \\
\text { premature } \\
\text { infants }\end{array}$ & $\begin{array}{l}\text { Frequency: once } \\
\text { a day } \\
\text { Duration of } \\
\text { study: } 1 \text { day } \\
\text { Duration of } \\
\text { intervention: } 20 \\
\text { minutes }\end{array}$ & $50-60 \mathrm{~dB}$ & $\begin{array}{l}\text { There was no significant difference } \\
\text { in mean of oxygen saturation, } \\
\text { respiratory rate, and pulse among } 4 \\
\text { groups following the intervention. }\end{array}$ \\
\hline
\end{tabular}




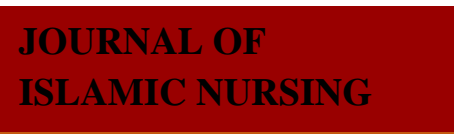

\begin{tabular}{|c|c|c|c|c|c|c|c|}
\hline No & $\begin{array}{c}\text { Author's Name } \\
\text { (Year) }\end{array}$ & Objective & Study Method & Sample & $\begin{array}{c}\text { Frequency, } \\
\text { Length \& } \\
\text { Duration of } \\
\text { Intervention }\end{array}$ & $\begin{array}{c}\text { Sound } \\
\text { Intensity }\end{array}$ & Result \\
\hline 3 & $\begin{array}{l}\text { Marofi et al } \\
\text { (2018) }\end{array}$ & $\begin{array}{l}\text { To evaluate the } \\
\text { impact of } \\
\text { Qur'an } \\
\text { recitation on } \\
\text { physiological } \\
\text { responses and } \\
\text { pain associated } \\
\text { with blood } \\
\text { sampling }\end{array}$ & $\begin{array}{l}\text { Clinical trial } \\
\text { with } \\
\text { randomization } \\
\text { and assigning } \\
\text { participants into } \\
\text { intervention and } \\
\text { control groups. }\end{array}$ & $\begin{array}{l}72 \text { neonates } \\
\text { admitted in } \\
\text { NICU }\end{array}$ & 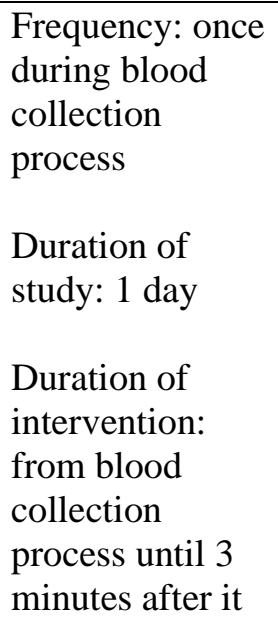 & $65 \mathrm{~dB}$ & $\begin{array}{l}\text { There was a significant increase in } \\
\text { pulse and respiratory rate in the } \\
\text { intervention group during blood } \\
\text { collection process compared to } \\
\text { their rates before and } 3 \text { minutes } \\
\text { after the procedure. } \\
\text { Oxygen saturation was } \\
\text { significantly lower throughout } \\
\text { blood sampling process in } \\
\text { comparison to its value before and } \\
3 \text { minutes following the procedure. }\end{array}$ \\
\hline 4 & Eskandari (2012) & $\begin{array}{l}\text { To investigate } \\
\text { the effect of } \\
\text { Qur'an therapy } \\
\text { on physiological } \\
\text { responses in } \\
\text { premature } \\
\text { infants }\end{array}$ & $\begin{array}{l}\text { Double blind } \\
R C T \text { which } \\
\text { assigned } \\
\text { participants into } \\
\text { control and } \\
\text { experiment } \\
\text { groups }\end{array}$ & $\begin{array}{l}120 \\
\text { premature } \\
\text { infants in } \\
\text { NICU }\end{array}$ & $\begin{array}{l}\text { Frequency: once } \\
\text { in the morning } \\
\text { Duration of } \\
\text { study: } 1 \text { day } \\
\text { Duration of } \\
\text { intervention: } 20 \\
\text { minutes }\end{array}$ & $50-60 \mathrm{~dB}$ & $\begin{array}{l}\text { There was significant difference in } \\
\text { respiratory rate and oxygen } \\
\text { saturation among participants in the } \\
\text { intervention group in } 3 \text { stages of } \\
\text { data collection }(\mathrm{p}<0,0001) \\
\text { There was a significant difference } \\
\text { in heart rate } 10 \text { minutes after the } \\
\text { intervention. }\end{array}$ \\
\hline 5 & $\begin{array}{l}\text { Majidipour et al } \\
\text { (2018) }\end{array}$ & $\begin{array}{l}\text { To identify the } \\
\text { impact of } \\
\text { Qur'an therapy } \\
\text { on physiological } \\
\text { responses in }\end{array}$ & $\begin{array}{l}\text { Randomized } \\
\text { Clinical Trial }\end{array}$ & $\begin{array}{l}56 \\
\text { premature } \\
\text { newborns } \\
\text { admitted in } \\
\text { NICU } \\
\end{array}$ & $\begin{array}{l}\text { Frequency: } \\
\text { Once } \\
\text { Duration of } \\
\text { study: } 1 \text { day }\end{array}$ & $50-55 \mathrm{~dB}$ & $\begin{array}{l}\text { Heart rate was significantly lower } \\
\text { in the intervention group }(\mathrm{p}<0,005) \\
\text { in } 6 \text { sessions of evaluation. } \\
\text { There was a significant difference }\end{array}$ \\
\hline
\end{tabular}




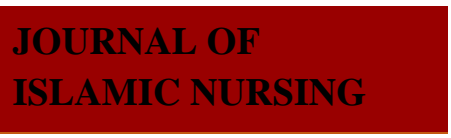

\begin{tabular}{|c|c|c|c|c|c|c|c|}
\hline No & $\begin{array}{c}\text { Author's Name } \\
\text { (Year) }\end{array}$ & Objective & Study Method & Sample & $\begin{array}{c}\text { Frequency, } \\
\text { Length \& } \\
\text { Duration of } \\
\text { Intervention }\end{array}$ & $\begin{array}{c}\text { Sound } \\
\text { Intensity }\end{array}$ & Result \\
\hline & & $\begin{array}{l}\text { premature } \\
\text { infants during } \\
\text { and after } \\
\text { phlebotomy }\end{array}$ & & & $\begin{array}{l}\text { Duration of } \\
\text { intervention: } 25 \\
\text { minutes, } \\
\text { consisting of } 20 \\
\text { minutes before } \\
\text { intervention and } \\
5 \text { minutes } \\
\text { during } \\
\text { intervention. }\end{array}$ & & $\begin{array}{l}\text { in respiratory rate } 20 \text { minutes } \\
\text { following intervention }(p=0,039) \\
\text { Oxygen saturation was } \\
\text { significantly higher in the } \\
\text { intervention group }(\mathrm{p}<0,05)\end{array}$ \\
\hline
\end{tabular}




\section{DISCUSSION}

Various interventions in care environment may result in pain and physiological alterations in newborns. Physiological changes could increase metabolism rate, body temperature, and heart rate which lead to higher respiratory rate, pulse, and blood pressure (Marofi et al., 2018), as well as lower oxygen saturation (Majidipour et al., 2018). Pain that is experienced during neonatal stage may cause neurological disorder, learning development, and behavioral disorder in children (Yamada et al., 2008).

Qur'an recitation therapy is revealed to be able to reduce heart rate, respiratory rate, and significantly increase oxygen saturation in the intervention group, as reported by Keshavars et al's study (2010) which involved 120 premature infants in NICU. The study revealed a significant difference in respiratory rate, pulse, and oxygen saturation between intervention and control group in the end of intervention and 10 following the intervention. The Qur'an therapy provided positive results on stability of vital signs and increase in oxygen saturation in patients with altered consciousness who were admitted in Intensive Care Unit (Mirzaeian, Shirvani, Alidosti, \& BabaeiHeydarabadi, 2017). Mansouri et al (2017) expressed that sound of Qur'an reduced arterial pressure, heart rate, and breathing frequency as well as improved oxygen saturation in patients admitted in ICU following Qur'an recitation intervention.

A study conducted by Daud \& Sharif (2018) reported that by evaluating diastole frequency through simple circuit connencting stetoscop and laptop in the group of participants listening to Qur'an recitation for 3 minutes before, during, and after listening to Qur'an, revealed a significantly lower diastole frequency up to $8.6 \%$ or $60 \mathrm{~Hz}$ to $80 \mathrm{~Hz}$ than before listening to Qur'an. It suggested that Qur'an recitation provided relaxing effect and calmness. Qur'an recitation also positively affected vital signs and improved level of consciousness in patients admitted in ICU (El-hady \& Kandeel, 2017; Nasiri et al., 2017).

A study conducted by Amini et al (2013) reported that providing lullaby and classical music significantly affected respiratory and heart rate; however, there was no significant difference in oxygen saturation during the intervention. Caparoz-Gonzales et al's study (2017) which involved premature infants demonstrated lower pulse and respiratory rate in the intervention group and higher pulse and respiratory rate in the control group. Lullaby may lower heart rate and improve oxygen saturation in neonates admitted in NICU (Taheri, Kargar, Abbasi, \& Hojat, 2017). Qur'an recitation therapy is a therapy that provides audio stimulation. Sound is a therapy that may serve as a cure through harmony (Hashim, Sha, \& Zainuddin, 2017) and generates higher alpha wave than music (Zulkurnaini, Shilawani, Kadir, Murat, \& Isa, 2012), thus produces soothing effect on individual.

\section{CONCLUSION}

Qur'an recitation therapy provided positive results on physiological responses in neonates admitted in NICU, including reducing heart rate, respiratory rate, and increasing oxygen saturation. The therapy may be implemented as complementary and supportive intervention to improve stability of physiological responses in neonates admitted in NICU, as well as non-pharmacological and non-invasive option of therapy.

\section{REFERENCE}

Abbas, A. M., El-Houfey, A. A., Abdelbadee, A. Y., Ali, M. K., Ali, S. S., Abdelrahman, R. M., \& Tolba, S. M. (2016). Effects of listening to Qur'an on maternal \& neonatal outcomes among mothers undergoes cesarean section. International Journal of Nursing and Health Related Case, 2(2), 39-53. 
Amini, E., Rafiei, P., Zarei, K., Gohari, M., \& Hamidi, M. (2013). Effect of lullaby and classical music on physiologic stability of hospitalized preterm infants: A randomized trial. Journal of Neonatal-Perinatal Medicine, 6, 295301. https://doi.org/10.3233/NPM1371313

Boxwell, G. (2010). Neonatal intensive care nursing (2nd). USA: Taylor \& Francis e-Library.

Brown, G. (2009). NICU noise and the preterm infant. Neonatal Network, $28(3)$, 165-173. https://doi.org/10.1891/07300832.28.3.165

Caparros-Gonzales, R.A., TorreLuque, A., Diaz-Pedra, C., Vico, F.j ., Buela-Casal, G. (2017). Listening to Relaxing Music Improves Physiological Responses in Premature Infants. Advances in Neonatal Care, $0(0), \quad 1-12$. https://doi.org/10.1097/ANC.0000000 000000448

Cong, X., Ludington-hoe, S. M., Mccain, G., \& Fu, P. (2009). Early Human Development Kangaroo Care modi fi es preterm infant heart rate variability in response to heel stick pain: Pilot study. Early Human Development, 85(9), 561-567. https://doi.org/10.1016/j.earlhumdev. 2009.05.012

Cruz, M. D., Fernandes, A. M., \& Oliveira, C. R. (2016). Epidemiology of painful procedures performed in neonates: A systematic review of observational studies. European Journal of Pain, 20, 489-498. https://doi.org/10.1002/ejp.757

Daud, N.F., Sharif, Z. (2018). Effect of listening to the Al-Quran on heart sound. IOP Conf. Series: Materials
Science and Engineering, 341(12023). https://doi.org/10.1088/1757-

899X/341/1/012023

El-hady, M. M., \& Kandeel, N. A. (2017). The effect of listening to Qur ' an on physiological responses of mechanically ventilated muslim patients. IOSR Journal of Nursing and Health Science, 6(5), 79-87. https://doi.org/10.9790/19590605097987

Eskandari, N., Alipour, Z., Tehran, H. A., Kamal, S., Hossaini, E., \& Sangi, S. (2014). Effect of vocal stimulation on responses of premature infants: A randomized controlled trial. Health, Spiritual Med Ethics, 1(1), 9-16.

Eskandari, N., Keshavars, M., Ashayeri, H., Jahdi, F., \& Hosseini, A.F. (2012). Quran recitation: Short term and related factor in preterm newborn. Research Journal of Medical Sciences, 6(3), 148-153.

Hashim, R., Sha, M., \& Zainuddin, Z. I. (2017). Healing with sound: Exploring possible applications of Qur anic recitation in cell culture. Revelation and Science, 7(1), 32-41.

Hunt, K. N. (2011). The NICU: Environmental effects of the Neonatal Intensive Care Unit on infants and caregivers. Research Papers. Southern Illinois University.

Keshavars, M., Eskandari, N., Jahdi, F., Ashaieri, H., Hosseini, F., \& Kalani, M. (2010). The effect of holly Quran recitation on physiological responses of premature infant. Koomesh Journal, 11(3), 77-169.

Kleijnen, J., Ioannidis, J. P. A., Moher, D., Mulrow, C., Clarke, M., Gøtzsche, P. C., ... Devereaux, P. J. (2009). The PRISMA statement for reporting systematic reviews and 
meta-analyses of studies that evaluate health care interventions: explanation and elaboration. Journal of Clinical Epidemiology, 62(10), e1-e34. https://doi.org/10.1016/j.jclinepi.2009 .06 .006

Loewy, J., Stewart, K., Dassler, A., Telsey, A., \& Homel, P. (2013). The effects of music therapy on vital signs, feeding, and sleep in premature infants. Pediatrics, 131(5), 902-918. https://doi.org/10.1542/peds.20121367

Majidipour, N., Nirouzad, F., Madmoli, Y., Sarrafzade, S., Aghababaeian, H., \& Borujeni, S. H. (2018). The effect of holy Quran recitation on the physiological responses of premature infants during phlebotomy: A randomized clinical trial. International Journal of Pediatrics, 6(55), 7869-7881. https://doi.org/10.22038/ijp.2017.242 03.2038

Mansouri, A., Vahed, A. S., Sabouri, A. R., Lakzaei, H., \& Arbabisarjou, A. (2017). Investigating aid effect of holy Quran sound on blood pressure, pulse, respiration and $\mathrm{O} 2$ sat in ICU patients. International Juornal of Scientific Study, 5(7), 1-5. https://doi.org/10.17354/ijssI/2017/1

Marofi, M., Abedini, F., Shirazi, M., Badiei, Z., \& Nikobakht, F. (2018). Effect of the sound of the holy Quran on the physiological responses and pain caused by blood sampling from the heels of hospitalized neonates at the Neonatal Intensive Care Unit. Iranian Journal of Neonatology, 9(3), 57-63.

https://doi.org/10.22038/ijn.2018.281 02.1376 .

Mirzaeian, R., Shirvani, M., Alidosti, M., \& Babaei-Heydarabadi, A. (2017). The effect oh holy Qur'an recitation sound on vital signs and arterial oxygen pressure of consciuos patients hospitalized in ICU. Indo American Journal of Pharmaeutical Sciences, 4(5), 1254-1259.

Nasiri, A. A., Shahdadi, H., \& Bandani, E. (2017). An investigation into the effect of listening to the voice of the holy Quran on vital signs and consciousness level of patients admitted to the ICU wards of Zabol University of Medical Sciences Hospitals. World Family Medicine, 15(10), 75-79. https://doi.org/10.5742/MEWFM.201 7.93142 .

Qolizadeh, A., Myaneh, Z. T., \& Rashvand, F. (2018). Investigating the effect of listening to the holy Qur'an on the physiological responses of neonates admitted to neonatal intensive care unit: A pilot study. Advances in Integrative Medicine. https://doi.org/10.1016/j.aimed.2018.0 8.004

Rabold, S. (2013). The effects of music therapy in the NICU on behavior, weight, and length of stay: A systematic review. Thesis. California State University San Marcos.

Shekha, M. S., Hassan, A. O., \& Othman, S. A. (2013). Effect of Qur'an listening and music on electroencephalogram brain waves. Egypt. J. Exp. Biol (Zool), 9(1), 119121.

Taheri, L., Kargar, M., Abbasi, M., \& Hojat, M. (2017). Effect of recorded male lullaby on physiologic response of neonates in NICU. Applied Nursing Research, 33, 127-130. https://doi.org/10.1016/j.apnr.2016.11 .003 .

Wachman, E. M., \& Lahav, A. 
(2010). The effects of noise on preterm infants in the NICU. Arch Dis Child Fetal Neonatal Ed, 96(4), F1F5.

https://doi.org/10.1136/adc.2009.1820 14.

Yamada, J., Stinson, J., Lamba, J., Dickson, A., Mcgrath, P. J., \& Stevens, B. (2008). A review of systematic reviews on pain interventions in hospitalized infants. Pain Research \& Management, 13(5), 413-420.

Zulkurnaini, N. A., Shilawani, R., Kadir, S. A., Murat, Z. H., \& Isa, R. M. (2012). The comparison between listening to Al-Quran and listening to classical music on the brainwave signal for the alpha band. IEEE Computer Society, 181-186. 